\title{
Industrialization of cassava sector in Ghana: progress and the role of developing high starch cassava varieties
}

\author{
K. O. DANKWA* \& B. B. PEPRAH \\ (K.O.D \& B.B.P.: CSIR - Crops Research Institute, Fumesua - Kumasi, Ghana) \\ *Corresponding author's email: anionlives@gmail.com
}

\begin{abstract}
In Ghana, cassava is a marginalized crop in food policies due to low research attention given it. However, high starch in cassava root is an important characteristic that makes the crop a potential industrial cash crop. In light of this, the Government of Ghana in 2001 introduced the Presidential Special Initiative (PSI) on Cassava, which aimed at industrializing the cassava sector for job creation and livelihood improvement through starch extraction. One of the import industrial products from cassava starch is ethanol. Ethanol is reported as the largest opportunity for cassava industrialization in Ghana followed by food-grade starch. However, the local ethanol consuming industry, Kasapreko, operates by importing over 25 million litres of ethanol every year due to inadequate supply of ethanol from local starch factories. This situation exists because of lack of cassava varieties that can yield more starch ( $75 \%$ or more) per total dry weight to feed the starch factories for sustainable production. Therefore, this review explores the relevance of developing high starch yielding cassava to the industrialization of the cassava sector in Ghana and lessons to learn from the success story of Thailand, the country with the world's most industrialized cassava sector.
\end{abstract}

Keywords: cassava; starch; waxy-starch; industrialization; processing

Subject Review Article. Received 15 May 15; revised 26 Aug 19

\section{Introduction}

Cassava (Manihot esculenta Crantz) is an important staple in the world. Over half a billion people depend on cassava for livelihood of which 300 million are in Africa. However, in addition to direct human and animal consumption of cassava roots, cassava starch has great potential in industry (Naziri et al., 2014; RTIP, 2004; FAO, 2001). Starch constitutes the main component of cassava root and plays an important role in the usage of the crop both for food and non-food purposes (Ceballos et al., 2006). Cassava stands as one of the most important sources of commercial production of starch in tropical and subtropical countries (Moorthy, 2002). The demand for starch as an industrial raw material for both food processing industries such as the pastries producers and non-food industries such as the pharmaceutical and the textile producers have been on the rise recently. According to a study by Grow Africa in 2015, the total latent demand of cassava starch as an industrial raw material is estimated to grow to 1.6 million MT per year, accounting for both domestic demand from Ghanaian industries and regional demand from

Ghana Jnl Agric. Sci. 54 (2), 79 - 85 
other ECOWAS markets. This presents a great economic opportunity for cassava producers in Ghana and the "Ghana Beyond Aid" agenda by the current government which seeks to decrease the nation's dependency on foreign aids through increased local production and export revenue. Cassava starch is extensively used for sizing and dyeing in the textile industries to increase brightness and weight of the cloth while in the pharmaceutical industries, it serves as a filler material and bonding agent for making tablets (Singh et al., 2003; Graffham et al., 1998). Factors that hinder successful industrialization of the cassava sector in Ghana range from limited industrial large scale processing (Grow Africa, 2015) to yield gap (4-12MT/ ha compared to a potential yield of $25-30 \mathrm{MT} /$ ha) (SRID, 2017). However low starch yielding ability of available cassava varieties also poses a major threat to industrialization of the cassava sector. Compared to the reports of cassava researchers from other parts of the world, cassava varieties in Ghana are not giving the optimum starch content. The best performing starch yielding cassava variety in Ghana, CRI-Sika bankye yields only $57.26 \%$ starch of its dry root weight (WAAPP, 2015) which is less than $73 \%-84 \%$ starch yield reported for cassava by other researchers (Sanchez et al., 2009; Baguma, 2004). Therefore, this review seeks to explore the benefits of enhancing the starch content of cassava varieties in Ghana and developing varieties with improved starch yielding qualities to better fit the need of different industries to contribute to the industrialization of the cassava sector in Ghana.

\section{Results}

Progress and Prospects of industrializing the cassava sector of Ghana

Ethanol production, especially for local consumption, is the largest opportunity for industrializing the cassava sector in Ghana. The demand for ethanol for both food and non-food industries has been increasing over the years. Over 60 million litres of ethanol is imported every year into Ghana (Grow Africa, 2015). About 25 million litres of total annual imported ethanol is used by only one local beverage manufacturer called Kasapreko which invested about 7.5 million USD into the production of ethanol by local producers as part of the company's strategic program to source local raw material and create jobs (Quashie, 2014).

The Grow Africa (2015) report on market opportunities of cassava in three African countries (Mozambique, Ghana and Nigeria) and two Southeast Asia countries (Thailand and Vietnam) describes the Ghana cassava sector as slightly commercial with low supply volumes and unsustainable as shown in figure 1 below. 


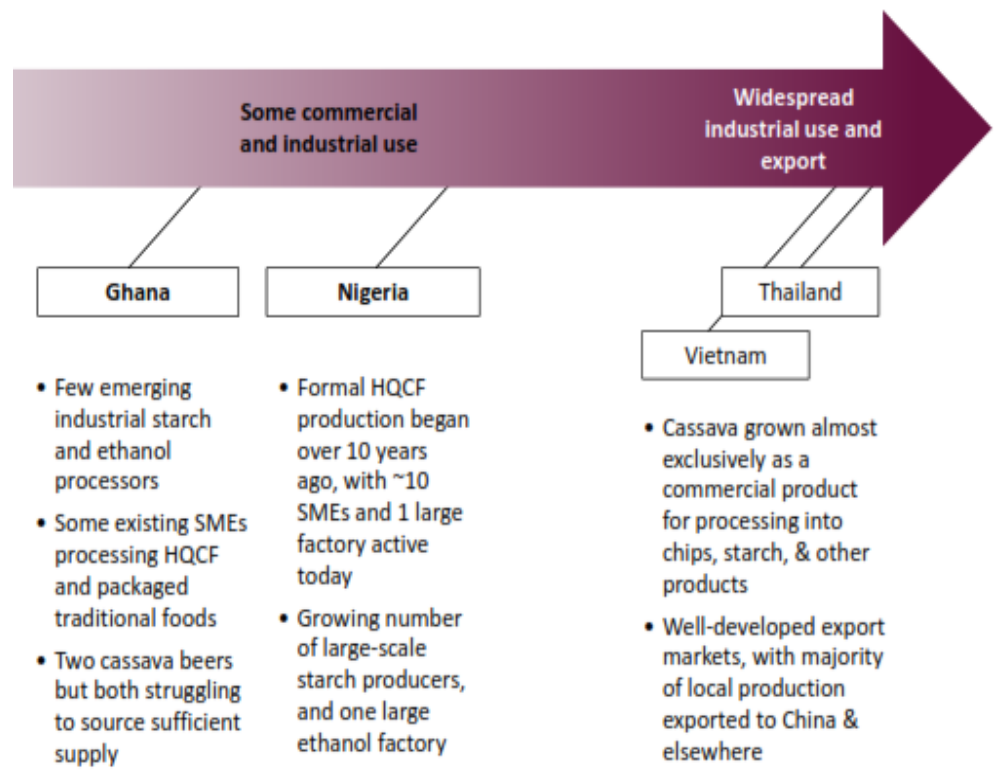

Source: Grow Africa (the sustainable trade initiative), 2015.

Fig. 1: Comparison of progress of Ghana cassava sectors industrialization to that of Nigeria Thailand and Vietnam.

The constraints of starch producing factories in Ghana

In Ghana, cassava is chiefly used in a popular local staple called "fufu" (boiled and pounded fresh root). Good poundability is negatively affected by low dry matter, high fiber and high starch content of cassava root while elasticity and smoothness of pounded paste depend on the amylose content (Safo-Kantanka et al., 1997). Good poundabilliy trait is important in breeding superior cassava varieties in Ghana and a requirement for easy adoption of new cassava variety by farmers. For this reason, the currently best starch-yielding cassava variety (Sika bankye) released by Crop Research Institute (CRI) in 2015, yields $19.63 \%$ and $57.26 \%$ fresh and dry root starch respectively of its total root weight (WAAPP, 2015) though cassava is reported to be a high starch producer with levels between $73.7 \%$ and $84.9 \%$ of its total storage root dry weight (Sanchez et al., 2009; Baguma, 2004). Thus, many starch factories in Ghana will not be able to operate at efficient levels and would have to process large volume of fresh roots for a relatively small quantity of starch due to the low starch yielding ability of the currently available cassava varieties. There is, therefore, a need to improve the starch content of cassava varieties through breeding and crop management to meet the starch factories demand and industrial standards. Sourcing for high starch genotypes from IITA (International Institute of Tropical Agriculture) and CIAT (International Center for Tropical Agriculture) for hybridization program could contribute massively to developing cassava varieties that could yield about $75 \%-85 \%$ starch of their dry root weight. 
In modern business, manufacturing activities is comparatively competitive. Therefore, actors of all value-adding activities must operate at an efficient pace to maximize output and sustain production. The sustainability of starch factories in Ghana is heavily plagued with a very weak supply chain linkage resulting in factories operating below the capacity. However, with the availability of high starch varieties that can yield about 75\% - 85\% starch of their total dry root weight, starch factories will not only be able to increase productivity to meet consumption demand but also less land area will be needed for cassava cultivation to feed the starch industries for sustainable production and supply.

Need for diverse novel cassava starch for different applications

Cassava starch is an essential raw material for food and non-food industries worldwide (Mweta, 2009). Over the years, there has been an increasing need for diverse novel starches (waxy and non-waxy types) for both food and non-food applications. The quality characteristics of cassava starch indicate its potential use either in the food or non-food industry; the waxy type of cassava starch is preferred in the food industry (Sanchez et al., 2010). Waxy starch is amylose-free and very important especially to the food industry because of its freeze-thaw stability (Ceballos et al., 2007). High viscosity is an indication of good quality starch (Dzogbefia et al., 2008). Starch is incorporated in many foods ranging from pastries to noodles and other staple foods (Dankwa et al., 2017). Some of these products are usually exposed to temperature fluctuations during preparation or storage and the freezethaw stability of starch in these products is very important to maintain the textural quality of the product after production and during storage.
Although a lot of work has been done on physicochemical properties (granule structure, pasting properties, swelling power and solubility) of cassava in Ghana and around the world, however, there is limited research on amylose-free cassava in Ghana (Charles et al., 2004; Gomes et al., 2005; Zaidul et al., 2007). There is a clear genetic influence on the content of amylose in the starch, and neither the age of the plant nor environmental factors seem to play a major role in determining it (Ceballos, 2007). Therefore, it will be of great importance for cassava breeders in Ghana to introduce amylose-free cassava genetic materials from research centers such as CIAT (international center for tropical agriculture) where the first natural waxy cassava genotype (AM206-5) was discovered (Sanchez, 2010).

\section{Discussion}

Growing international cassava market and Lessons from Thailand's success story $\mid$

The global trade in cassava products has been growing rapidly in recent years, largely driven by Chinese imports and Thai and Vietnamese exports. The cassava starch has a competitive advantage for ethanol production than other materials (FAO 2010; Sriroth et al. 2010; Nguyen et al. 2007). China now imports millions of tons of cassava chips to make ethanol and invested 1 billion USD in cassava in Tanzania, a country with only 5.5MT annual production compared to $16.5 \mathrm{MT}$ of Ghana (FAOSTAT, 2013; DATCO, 2017). Increasingly and undoubtedly, cassava is becoming one of the major crops that is fast turning into cash crops globally. For example, cassava starch plays a major role in generating income in many tropical countries like Thailand and Vietnam (Sriroth et al. 2000). Thailand's earnings from the export of cassava products reached nearly 
$\$ 2.8$ billion in 2014 , having grown at about 15\% annually since 2010 (Grow Africa, 2015). The modern starch manufacturing process was developed in Thailand due to the significantly increased demand for cassava starch in the local market (Piyachomkwan \& Tanticharoen, 2011). The rising demand for cassava starch at both the local and international market presents a great opportunity for Ghana to enhance foreign exchange revenue through export and improve farmers' livelihood through improved income. Thailand's success story of a highly industrialized cassava sector is also largely due to the intense research attention given to the crop that led to the development of high-yielding cassava varieties as well as the promotion of the use of cassava starch in the manufacturing sector. Cassava, though not a staple, continues to play a major role in Thailand's economy through export as fuel (ethanol) or feed (Treesilvattanakul, 2016). Thus, research attention, promotion, education, and government policies are the pivot around which successful industrialization of the cassava sector in a country revolves. The Thailand cassava industrialization success story and how it was done presents great lessons and opportunities to African countries that produce a lot of cassava yet gain relatively little to nothing from their cassava sector due to limited industrialization.

\section{Conclusion}

Research and development attention for cassava starch production presents a great opportunity for industrialization of the cassava sector in Ghana. The available best high starch yielding variety in Ghana (57\% starch of its total dry root weight) is below the attainable yield of $75 \%-85 \%$. There is, therefore, the need to improve on cassava varieties that can yield about
$70 \%$ or more starch of its total dry weight to meet the growing demand. Furthermore, there is a need to develop cassava with specific characteristics to fit diverse industries. For example, developing waxy cassava (amylose-free starch) for the food industries especially frozen foods and developing high amylose starch for the adhesive-making industries. The success story of Thailand indicates that successful industrialization of the Ghana cassava sector hinges on Government policies that gear towards funding Research and Development (R\&D) in aid of high-quality starch yielding cassava variety as well as promoting civil and industrial education on the uses of cassava starch.

\section{Acknowledgement}

Special appreciation goes to Mr. Bright Boakye Peprah for his enormous contribution and the CSIR - Crop Research Institute's library.

\section{REFERENCES}

Baguma, Y. (2004) Regulation of starch synthesis in cassava. Doctoral Thesis, Swedish university of agricultural sciences, Uppsala, Sweden.

Ceballos, H, Sanchez, T., Morante, N., Fregene, M., Dufour, D., Smith, A., Denyer, K., Perez, J., Calle, F. \& Mestres, C. (2006) Discovery of an Amylose-free Starch Mutant in Cassava. (Manihot esculenta Crantz) Journal of Agricultural and Food Chemistry 55 (18), $7469-7476$.

Ceballos, H., Sánchez, T., Morante, N., Fregene, M., Dufour, D. \& Smith, A. M. (2007) Discovery of an amylose-free starch mutant in cassava (Manihot esculenta Crantz). Journal of Agricultural and Food Chemistry 55, 7469 7476. doi: 10.1021/jf070633y

Charles, A., Chang, Y., KO, W., Sriroth, K. \& Huang, T. (2004) Some Physical and 
Chemical Properties of Starch Isolates of Cassava Genotypes. Starch/Stärke 56, 413 418.

Dankwa, KO., Liu, YJ. \& Pu, ZE. (2017) “Evaluating the nutritional and sensory quality of bread, cookies and noodles made from wheat supplemented with root tuber flour", British Food Journal 119 (4), 895 - 908. doi: 10.1108/ BFJ-09-2016-0414.

Dutch Agricultural Development \& Trading Company (DATCO) (2017) Revisiting Cassava as Industrial Crop with One District One Factory - Using DADTCO Experience.

Dzogbefia, VP., Ofosu, GA. \& Oldham, JH. (2008) Physicochemical and pasting properties of cassava starch extracted with the aid of pectin enzymes produced from Saccharomyces cerevisiae ATCC52712. Scientific Research and Essays 9, 406 - 409.

FAO. (2010) Bioenergy and Food Security: the BEFS Analysis for Thailand. Food and Agriculture Organization of the United Nation, Rome.

FAOSTAT. (2013) Cassava production in East Africa. FAO of UN. Rome, Italy.

FAO. (2001) The state of world cassava. FAO of UN. Rome, Italy.

Gomes, A., Mendes da Silva, C. \& Ricardo, N. (2005) Effects of annealing on the physicochemical properties of fermented cassava starch (polvilho azedo). Carbohydrate Polymers 60, $1-6$.

Graffham, AJ., Dziedzoave, NT. \& Ayenor, GS. (1998) Expanded Markets for locally produced Cassava Flours and Starches in Ghana. Final technical report R6504, Crop post-harvest program - Department for International Development.

Grow Africa. (2015) Market opportunities for commercial cassava in Ghana, Mozambique and Nigeria. The sustainable trade initiative study report. pp. $18-21$.

Moorthy, SN. (2002) Physicochemical and functional properties of tropical tuber starches. Starch/ Starke 54, 559 - 592.

Mweta, ED. (2009) Physiochemical, functional and structural properties of native Malawian cocoyam and sweet potato Starches. PhD. Thesis submitted to University of Free State Bloemfontein South Africa.

Naziri, D., Quaye, W., Siwoku, B., Wanlapatit, S., Phu, TV. \& Bennett, B. (2014) The diversity of postharvest losses in cassava value chains in selected developing countries. Journal of Agriculture and Rural Development in the Tropics and Subtropics 115 (2), 111 - 123.

Nguyen, TLT., Gheewala, SH. \& Garivait, S. (2007) Energy balance and GHG-abatement cost of cassava utilization for fuel ethanol in Thailand. Energy Policy 35. doi:10.1016/j. enpol.2007.03.012.

Piyachomkwan, K. \& Tanticharo, M. (2011) Cassava industry in Thailand: prospects. The Journal of Royal Institute of Thailand (JRIT) 3, 160.

Quashie, C. (2014) The finder Newspaper. Local beverage manufacturers battle unfair taxes. Business News of Tuesday, 22 July 2014.

Root and Tuber Improvement Programme [RTIP] (2004) Ministry of Food and Agriculture. Cassava processing in Ghana: Information Guide. MOFA, Ghana.

Safo-Kantanka, O., Owusu-Nipah, J., Acquistucci, R., OseiMinta, M., Aubyn, A. \& Quansah, C. (1997) Contribution to the understanding of the cooking quality of cassava (Manihot esculenta Crantz). In: Improvement of basic food crops in Africa through plant breeding, including the use of induces mutations. Proceeding of a final research co-ordination meeting. FAO/IAEA. Rome, Italy. 121 - 129. 
Sanchez T, Dufour D, Morante N. \& Ceballos H. (2010) Discovery of natural waxy cassava starch. Evaluation of its potential as a new functional ingredient in food. International conference on food innovation. Date: 25 - 29 October, 2010. Venue: Polytechnic University of Valencia.

Sánchez T, Salcedo E, Ceballos H, Dufour D, Mafla G, Morante N. \& Moreno IX. (2009) Screening of Starch Quality Traits in Cassava (Manihot esculenta Crantz). Starch/ Stärke 61 (5), pp. 310.doi:10.1002/star.200990027

Singh N, Singh J, Kaur L, Sodhi NS. \& Gill BS. (2003) Morphological, Thermal and Rheological Properties of Starches from Different Botanical Sources. Food Chemistry $\mathbf{8 1}, 219-231$.

SRID (2017) Statistics Research and Information Directorate. Ministry of Food and Agriculture, Accra, Ghana.

Sriroth K., Piyachomkwan, K., Wanlapatit, S. \& Oates C. (2000) Cassava starch technology: the Thai experience. Starch/Stärke 52, 439 449.
Sriroth K., Piyachomkwan K., Wanlapatit S. \& Nivitchanyong, S. (2010) The promise of a technology revolution in cassava bioethanol: from Thai practice to the world practice. Fuel $89,1333-1338$.

Treesilvattanakul, K. (2016) Deterministic Factors of Thai Cassava Prices: Multi-Uses of Cassava from Food, Feed, and Fuel Affecting on Thai Cassava Price Volatility. 3 (2016), 121 - 129. ICoA Conference Proceedings, 7 - 9 November, 2015. Matsuyama, Japan.

West Africa Agricultural Productivity Programme (WAAPP) (2015) Catalogue of crops variety released and registered in Ghana 1, 2 - 4 .

Zaidul, I., Norulaini, N., Omar, A., Yamauchi, H. \& Noda, T. (2007) RVA analysis of mixtures of wheat flour and potato, sweet potato, yam, and cassava starches. Carbohydrate Polymers 69, $784-791$. 